\title{
Operating room waste reduction in plastic and hand surgery
}

\author{
Mark G Albert MD, Douglas M Rothkopf MD
}

MG Albert, DM Rothkopf. Operating room waste reduction in plastic and hand surgery. Plast Surg 2015;23(4):235-238.

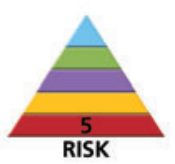

BACKGROUND: Operating rooms (ORs), combined with labour and delivery suites, account for approximately $70 \%$ of hospital waste. Previous studies have reported that recycling can have a considerable financial impact on a hospital-wide basis; however, its importance in the OR has not been demonstrated.

OBJECTIVE: To propose a method of decreasing cost through judicious selection of instruments and supplies, and initiation of recycling in plastic and hand surgery.

METHODS: The authors identified disposable supplies and instruments that are routinely opened and wasted in common plastic and hand surgery procedures, and calculated the savings that can result from eliminating extraneous items. A cost analysis was performed, which compared the expense of $O R$ waste versus single-stream recycling and the benefit of recycling HIPAA documents and blue wrap.

RESULTS: Fifteen total items were removed from disposable plastic packs and seven total items from hand packs. A total of US $\$ 17,381.05$ could be saved per year from these changes alone. Since initiating single-stream recycling, the authors' institution has saved, on average, US $\$ 3,487$ per month at the three campuses. After extrapolating at the current savings rate, one would expect to save a minimum of US $\$ 41,844$ per year.

DISCUSSION: OR waste reduction is an effective method of decreasing cost in the surgical setting. By revising the contents of current disposable packs and instrument sets designated for plastic and hand surgery, hospitals can reduce the amount of opened and unused material.

CONCLUSIONS: Significant financial savings and environmental benefit can result from this judicious supply and instrument selection, as well as implementation of recycling.

Key Words: Cost; Environment; Green; Hand; Plastic; Recycling; Waste

\section{La réduction des déchets en salle d'opération lors des chirurgies plastiques et de la main}

\begin{abstract}
HISTORIQUE : Les salles d'opération (SO) et les blocs de travail et d'accouchement produisent environ $70 \%$ des déchets hospitaliers. Selon des études antérieures, le recyclage a des conséquences financières importantes pour l'ensemble de l'hôpital. Cependant, son importance n'a pas été démontrée en SO.
\end{abstract}

OBJECTIF : Proposer une méthode pour réduire les coûts grâce à un choix judicieux d'instruments et de fournitures et au recyclage dans le cadre des chirurgies plastiques et de la main.

MÉTHODOLOGIE : Les auteurs ont ciblé les fournitures jetables et les instruments qui sont ouverts systématiquement et gaspillés lors des interventions courantes en chirurgie plastique et de la main et ont calculé les économies qui peuvent découler de l'élimination d'articles superflus. Ils ont procédé à une analyse des coûts, dans laquelle ils ont comparé la dépense de déchets en $\mathrm{SO}$ au recyclage à flux unique et l'avantage de recycler les documents et les emballages bleus conformément à la HIPAA.

RÉSULTATS : Quinze objets ont été retirés des emballages jetables pour la chirurgie plastique et sept autres, des emballages pour la chirurgie de la main. Au total, on pourrait épargner 17 381,05 \$US chaque année grâce à ces seuls changements. Depuis le début du recyclage à flux unique, l'hôpital des auteurs a épargné en moyenne 3487 \$US par mois sur ses trois campus. Après extrapolation aux taux d'économie actuels, on s'attendrait à épargner au moins 41844 \$US par année.

EXPOSÉ : La réduction des déchets en $\mathrm{SO}$ est une méthode efficace pour réduire les coûts en milieu chirurgical. En révisant le contenu des emballages jetables et des emballages d'instruments conçus pour la chirurgie plastique et la chirurgie de la main, les hôpitaux peuvent réduire la quantité d'équipement ouvert et inutilisé.

CONCLUSIONS : D'importantes économies et des avantages environnementaux marqués peuvent découler d'un approvisionnement judicieux et d'un choix d'instruments, de même que de l'adoption du recyclage.
$\mathrm{O}$ perating rooms (ORs), combined with labour and delivery suites, account for approximately $70 \%$ of hospital waste (1). Cost-saving initiatives have popularized the concept of reprocessing single-use devices; however, these reprocessed instruments are frequently not disinfected and sterilized properly $(2,3)$. We propose a method of decreasing cost through judicious selection of instruments and supplies used in plastic and hand surgery.

Other studies have shown that recycling can have a considerable financial impact on a hospital-wide basis; however, its importance in the OR has not been demonstrated. Recycling is a growing phenomenon in the United States, with $34.7 \%$ of all waste successfully recycled in 2011, representing an increase from 16\% in 1990 and $28.5 \%$ in 2000 . Health care centres are the second largest contributors to waste in the United States, with $>4$ billion tonnes of waste produced per year. ORs and labour/delivery specifically, account for $70 \%$ of all health care waste (1).

In the OR, inpatient and outpatient settings, commonly recycled materials such as plastic, paper, hard plastic, glass, metal and blue wrap are disposed of as general waste, resulting in financial losses and environmental harm. Single-stream recycling refers to a system in which all recyclable materials are collected in one collection bin and separated at a material recovery facility.

Blue wrap, a No. 5 plastic composed of polypropylene, is commonly used for wrapping instruments for sterilization and as a component of OR drapes and gowns. According to the University of Minnesota Medical Center (Minneapolis, Minnesota, USA), blue wrap is estimated to account for $19 \%$ of OR waste and $5 \%$ of all hospital waste. It is not biodegradable and also not widely recycled. A resale market has developed for this material because it can be melted to pellet form and sold to domestic companies for production of other No. 5 plastic items.

\section{METHODS}

The authors examined the current sets of disposable items and instruments designated for common plastic and hand surgery procedures at one teaching hospital affiliated with their institution. These procedures included breast reduction, breast augmentation, implant/expander removal, panniculectomy, abdominoplasty, carpal tunnel release, ganglion cyst excision, A1 pulley release, Dupuytren excision, tendon repair, fracture open reduction and internal fixation, and fracture closed reduction and percutaneous pinning. 
TABLE 1

Items removed from plastic and hand packs

\begin{tabular}{ll}
\hline Plastic & Hand \\
\hline 1 pack of gauze & 22 -gauge needle \\
Scratch pad & Plastic basin \\
2 Mastisol & 2 inch webril \\
2 packs of lap pads (5 each) & 4 inch webril \\
6 packs of steri strips & 2 cotton towels \\
3 cotton towels & Outer wrap dressing \\
\hline
\end{tabular}

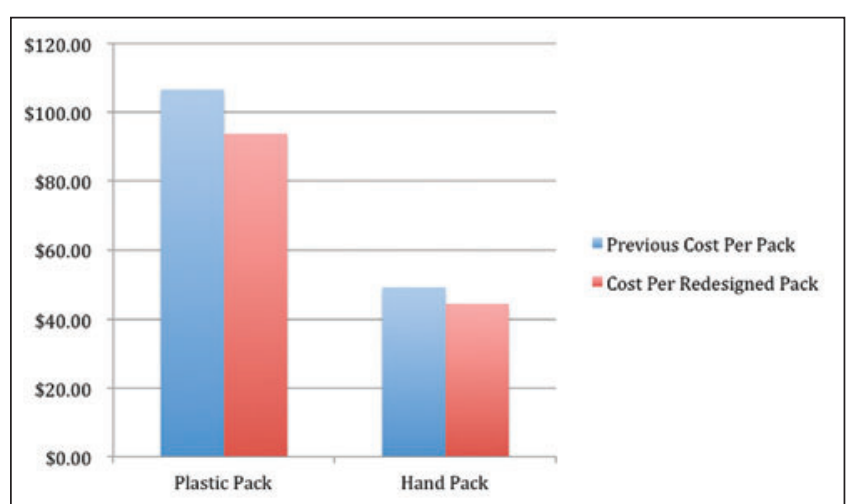

Figure 1) Cost of disposable packs

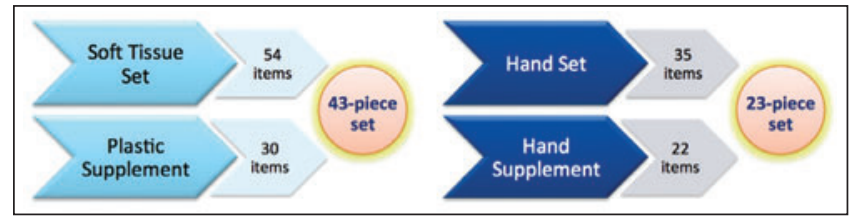

Figure 2) Consolidation of plastic and hand instrument sets

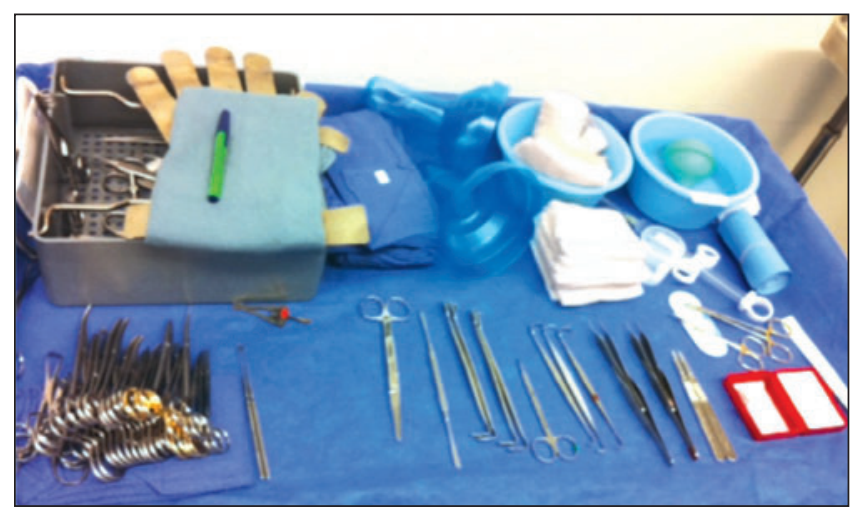

Figure 3) Hand set and disposable pack with eliminated instruments on left

The authors interviewed plastic and hand surgeons at their institution, and identified the supplies and instruments that are routinely opened and wasted. Then, savings from eliminating extraneous items were calculated and a cost analysis was performed. New disposable packs and instrument sets were created based on surgeons' responses.

At the University of Massachusetts' Hahnemann Campus, paper and plastic recycling began in January 2012. In April 2013, efforts resulted in the hiring of a new waste disposal company to introduce single-stream in the OR, inpatient and outpatient facilities at all three campuses. To date, single-stream recycling has been introduced in the OR setting for the Hahnemann campus only.

Blue wrap was also collected before patients entered ORs, and has been transported on a weekly basis to a local foundation free of charge since August 2013. Here, individuals with special needs are hired by the 'Blu2green' company to sew the blue wrap into products, such as shopping bags, wallets and neckties, which are sold for charity.

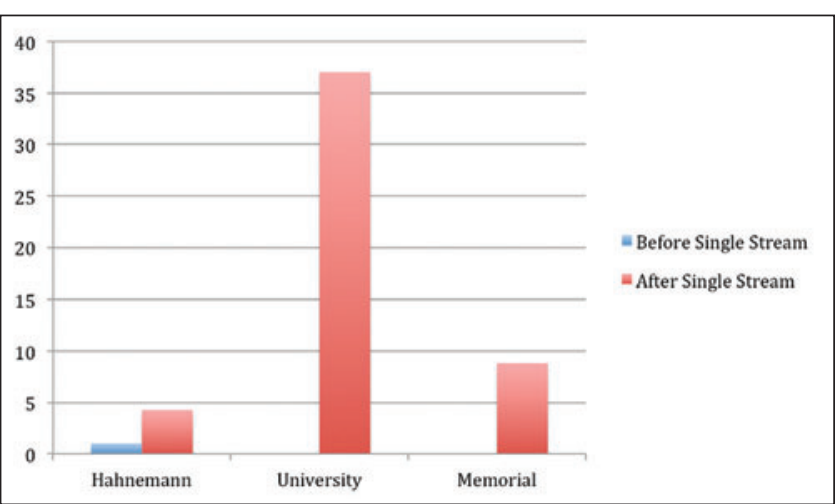

Figure 4) Average monthly recycling totals (tonnes) according to campus (University of Massachusetts, Worcester, Massachusetts, USA) before and after initiation of single stream recycling in April 2013

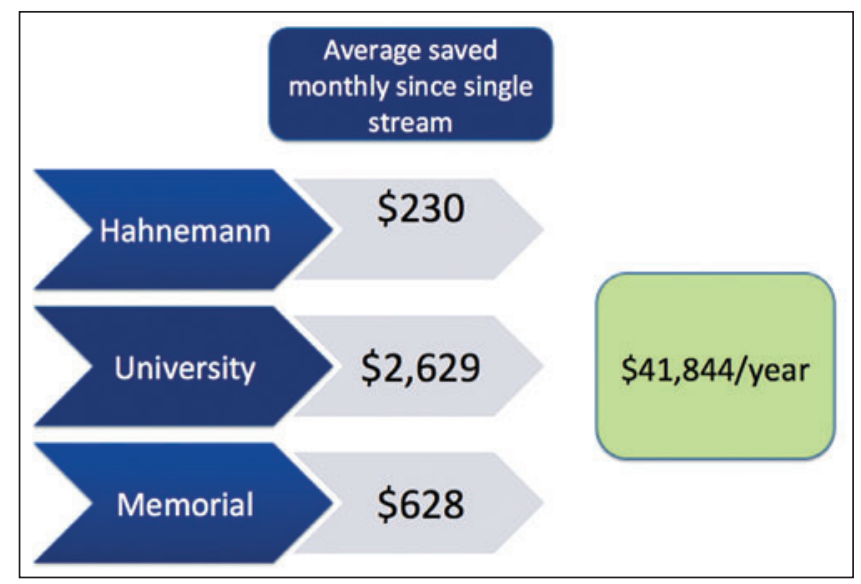

Figure 5) Average savings after single-stream recycling initiated

\section{RESULTS}

Fifteen total items were removed from the disposable plastic pack and seven total items from the hand pack (Table 1). After these changes to the disposable plastic packs, the cost per pack decreased from US\$106.64 to US\$93.79. Changes to the disposable hand pack resulted in a price decrease from $\$ 49.36$ per pack to US $\$ 44.56$ per pack (Figure 1). Based on the annual number of these common procedures performed, an estimated total of US $\$ 17,381.05$ could be saved per year from these changes alone.

The redesigned plastic instrument pack is composed of 43 instruments, compared with the 54-item soft tissue set and 30-instrument plastic supplement previously used. The new hand instrument set is composed of 23 total instruments, which is a reduction compared with the formerly combined 35-piece hand set and 22-piece fracture set (Figure 2 and Figure 3). These changes are potentially cost saving through reductions in autoclaving, labour and turnover time.

During the first months of recycling at the Hahnemann campus, an average of 1.03 tonnes/month was recycled. In April 2013, single-stream recycling was implemented. In the first nine months at the Hahnemann campus, an average of 4.28 tonnes/month was recycled, corresponding to an average recycling rate of $51 \%$. At the University campus, in April 2013, recycling rates went from an average of 0 tonnes/month to 37.0 tonnes/month, corresponding to an average recycling rate of 29\%. At the Memorial campus, also in April of 2013, recycling rates went from an average of 0 tonnes/month to 8.84 tonnes/month, corresponding to an average recycling rate of $20 \%$ (Figure 4).

Since initiating single-stream recycling (April 2013), the institution has saved, on average, US\$230 per month at Hahnemann, US\$2,629 per month at University and US\$628 per month at Memorial (Figure 5) campuses. After extrapolating at the current savings rate a savings of US\$41,844 per year is anticipated. 


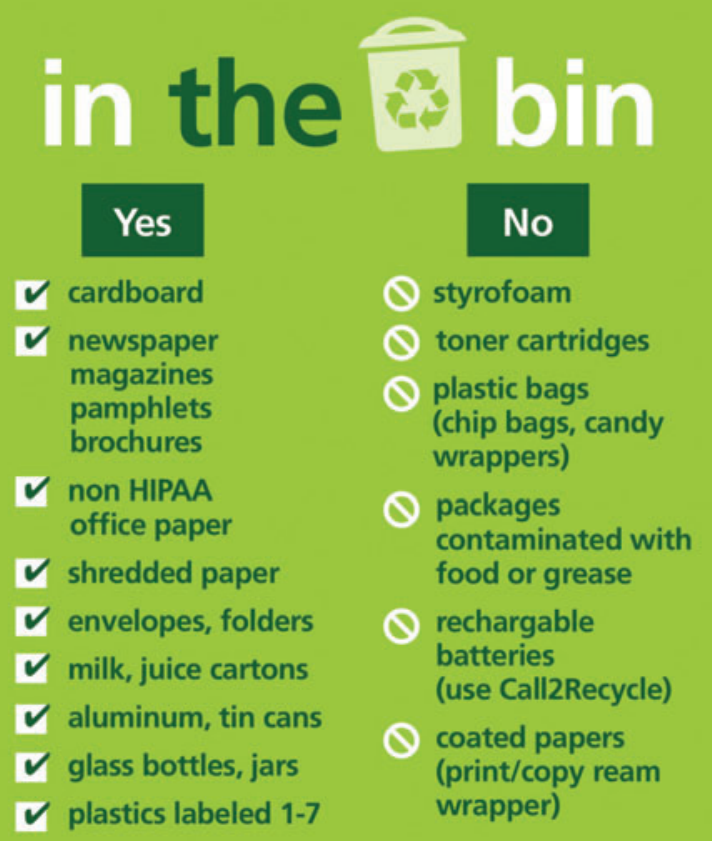

ARE YOU DOING YOUR PART?

For more about recycling, click on QRC code

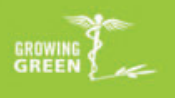

Figure 6) Recycling sign posted on all campuses of the University of Massachusetts, Worcester, Massachusetts, USA

The recycling of Health Insurance Portability and Accountability Act (HIPAA) documents began in January 2014. On doing so, the monthly recycling totals increased by 4 tonnes/month at Hahnemann, 17 tonnes/ month at University and 8 tonnes/month at Memorial campuses.

Since initiating the blue wrap program at the Hahnemann campus 10 months ago, 1.2 tonnes of blue wrap have been diverted, which accounts for a waste disposal savings of US $\$ 85$.

\section{DISCUSSION}

OR waste reduction is an effective method of cost reduction in the surgical setting. By revising the contents of current disposable packs and instrument sets designated for plastic and hand surgery, hospitals can reduce the amount of opened and unused material. Significant savings can result from this judicious supply and instrument selection.

The introduction of single-stream recycling provided a major increase in volume of recycling at the Hahnemann campus. While single-stream recycling has now been introduced at all three campuses, OR recycling is only currently occurring at our Hahnemann campus. Additionally, a physician- and nurse-driven recycling campaign has only been launched at the Hahnemann campus (Figures 6 to 8). These factors likely account for the considerable difference in recycling rates among campuses.

The estimate of US $\$ 41,844$ saved per year with single-stream recycling is conservative because it is based on monthly average savings at the beginning of our campaign. We plan to significantly increase our recycling volume totals as more patient floors, ORs, radiology suites, etc, slowly begin recycling. Capital gained from recycling could be used to implement a staff incentive program to improve compliance with our recycling program; providing free coffee or food to staff members may provide an impetus to improve recycling tendancies. In addition, greater savings will be witnessed in the future as the recycling program grows and requires higher volume collection equipment with the same number of transportation trips, resulting in lower disposal costs per tonne.

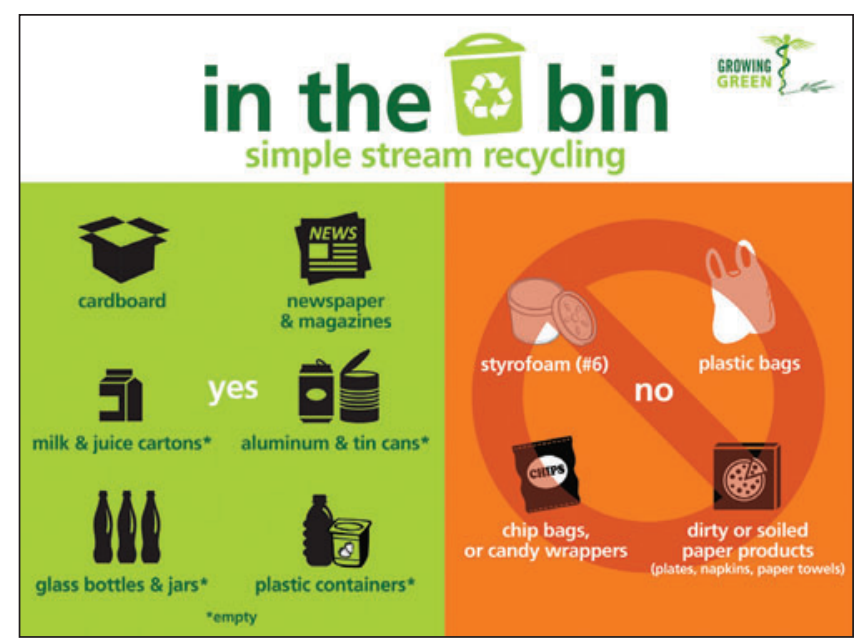

Figure 7) Recycling sign posted in eating areas

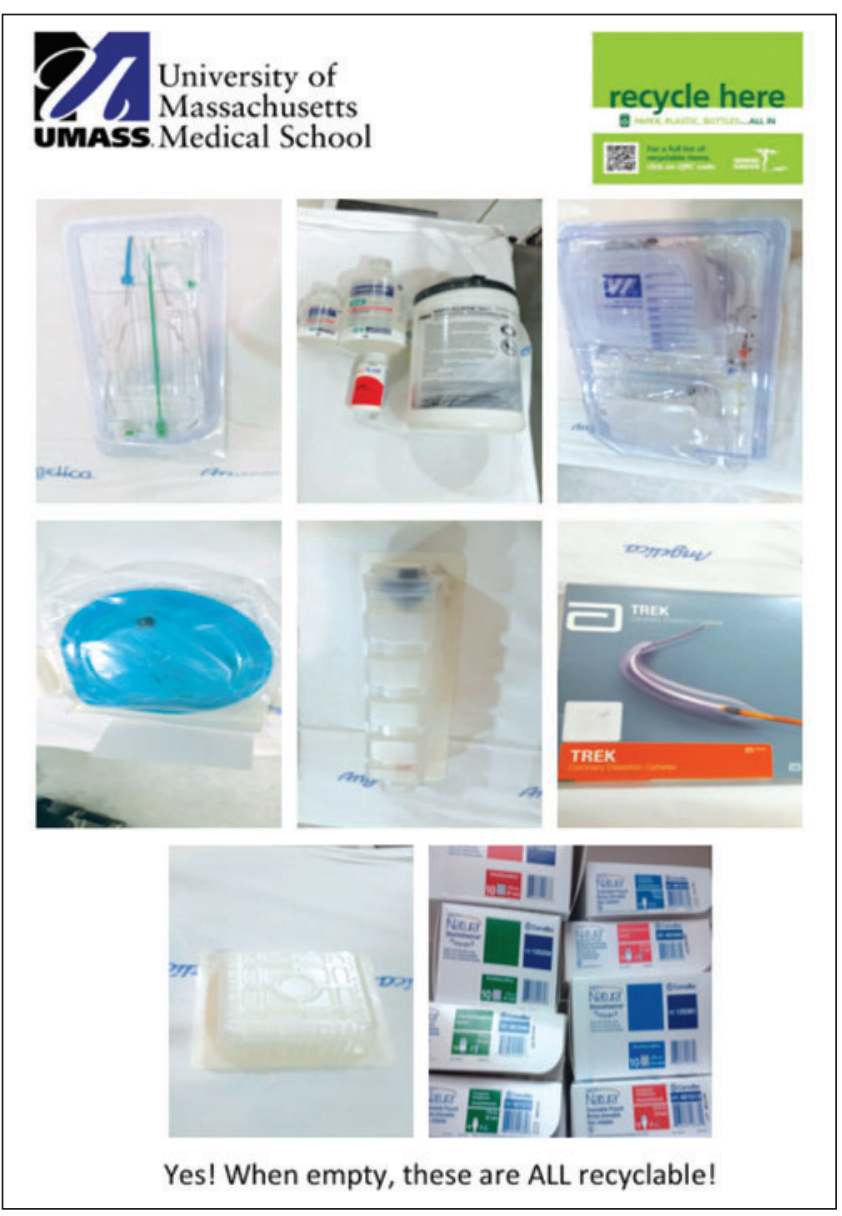

Figure 8) Recycling sign posted in the vascular suite

Our future plans include launching a campaign to publicize, simplify, and promote single-stream recycling at our other two campuses, similar to our efforts at Hahnemann. Additionally, we plan to introduce OR recycling at our other two campuses and investigate local blue wrap buyers and determine whether additional profit can be seen beyond the current savings from free disposal. We also plan to further investigate the impact of fluid collection systems in operating room waste reduction and cost savings. Additionally, we have been in discussion with administrators about purchasing reusable gowns and reusable instrument containers, and other reusable surgical devices. 
A team approach is critical for the success of these cost-saving endeavours. Infection control, environmental services, central sterile, nurses and management should be involved at the onset. We have found that new programs are more likely to succeed if instructions are simple and easy to follow. If interested in initiating cost-saving programs at your institution, checklists are available at www.greeningtheor.org. Begin by asking whether your institution is recycling and whether it is being done in the OR specifically. Where are documents from HIPAA bins being sent and how are they disposed of? Is blue wrap being collected? How aware are staff members about recycling practices? Who decides what items go into disposable packs and instrument sets?

Waste reduction is the responsibility of all health care providers; however, as leaders in the workplace, physicians should act as role models regarding proper disposal practices. In the end, it should be the surgeon's decision about what items are included and excluded from disposable packs and instrument sets. Initiation of single-stream recycling is crucial for social and environmental responsibility, and the cost saving aspect is particularly important given the uncertain financial future of health care in the United States. Implementation of these practices in all specialties, at all hospitals, will result in national, environmental and financial savings.
DISCLOSURES: The authors have no financial disclosures or conflicts of interest to declare.

\section{REFERENCES}

1. Kwakye G, Brat GA, Makary MA. Green surgical practices for health care. Arch Surg 2011;146:131-6.

2. Heeg P, Roth K, Reichl R, Cogdill CP, Bond WW. Decontaminated single-use devices: An oxymoron that may be placing patients at risk for cross-contamination. Infect Control Hospital Epidemiol 2001;22:542-9.

3. Favero MS. Requiem for reuse of single-use devices in US hospitals. Infect Control Hospital Epidemiol 2001;22:539-41.

4. Practice Greenhealth Initiative. Greening the OR Guidance Documents. <www.greeningtheor.org> (Accessed October 27, 2014).

5. US Food and Drug Administration. List of single-use devices known to be reprocessed or considered for reprocessing <www.fda.gov/ MedicalDevices/DeviceRegulationandGuidance/

ReprocessingofSingle-UseDevices/ucm121218.htm> (Accessed October 27, 2014).

6. Ridel LM. Environmental and financial impact of a hospital recycling program. AANA J 2011;79:8-14. 